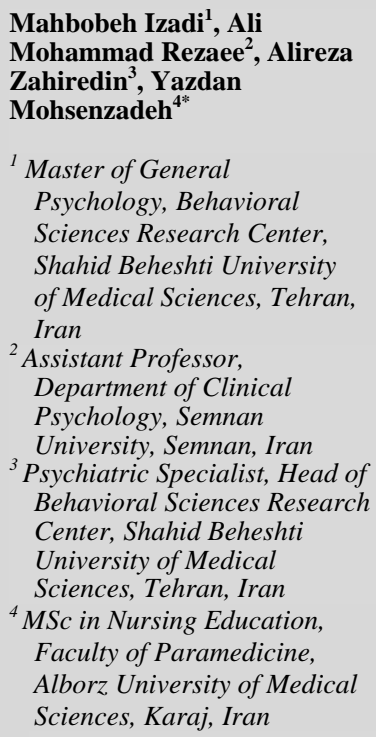

Mahbobeh Izadi ${ }^{1}$, Ali

Mohammad Rezaee ${ }^{2}$, Alireza

Zahiredin ${ }^{3}$, Yazdan

Mohsenzadeh ${ }^{4}$

${ }^{1}$ Master of General

Psychology, Behavioral

Sciences Research Center,

Shahid Beheshti University

of Medical Sciences, Tehran, Iran

${ }^{2}$ Assistant Professor,

Department of Clinical

Psychology, Semnan

University, Semnan, Iran

${ }^{3}$ Psychiatric Specialist, Head of

Behavioral Sciences Research

Center, Shahid Beheshti

University of Medical

Sciences, Tehran, Iran

${ }^{4} \mathrm{MSc}$ in Nursing Education,

Faculty of Paramedicine,

Alborz University of Medical

Sciences, Karaj, Iran

*Corresponding Author: MSc in Nursing Education,

Faculty of Paramedicine, Alborz

University of Medical Sciences,

Karaj, Iran

Tel: 026- 32755085

E-mail: Mohsenzadeh.y@gmail.com

\section{The Relationship Between Early Maladaptive Schemas, Attachment and Marital Satisfaction with Applicants for Separation}

Received:1 Dec. 2017; Accepted:9 Jan. 2018

\section{Abstract}

This study is aimed at inspecting the relationship between early maladaptive schemas and attachment and marital satisfaction with applicants for separation. This research depicts correlation and statistical of all referring applicants to mahalati family court of Tehran city. 415 applicants were selected among all applicants through available sampling method. The instrument used was the short form of the Young Schema Questionnaire, the Adult Attachment Scale Collins and Reid and marital satisfaction scale that were completed by participants. For data analysis, stepwise regression was used. The results show that there is a negative relationship between the components of attachment anxiety and intimacy and marital satisfaction, these two variables together explained $12 \%$ of variance in marital satisfaction. Also no significant relationship between attachment and marital satisfaction was found. In addition, there are negative relationships between the validity of maladaptive schemas and components, subjugation, failure, defectiveness, undeveloped self, insufficient self, social isolation, self-sacrifice, abandonment, and entitlement and these variables could total $43 \%$ of the variance marital satisfaction explained. Also mistrust variables, emotional inhibition and unrelenting standards don't have significant role of marital satisfaction. So early maladaptive schemas have greater impact on explaining the variance of marital satisfaction in comparison with attachment components.

Keywords: Early maladaptive schemas, Attachment, Marital satisfaction 


\section{رابطه طرحوارههاى ناساز كار اوليه و دلبستكى

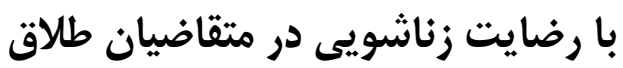

تاريخ دريافت مقاله: •99/9/1 ؛ تاريخ يذيرش:99/1/ \$

حكSه

مقدمه: رضايت زناشويى يكى جنبه بسيار مهم و يبيجيده از يك رابطه زناشويى است كه مى تواند به وسـيله عوامـل مهمسى

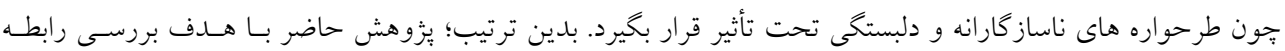
طرحوارههاى ناساز گار اوليه و دلبستخى با رضايت زناشويى در متقاضيان طلاق صورت گرفت. مواد و روش ها: طرح بزّوهش حاضر توصيفى از نوع همبستكى مى باشد و جامعسه آمـارى شـامل كليـه متقاضسيان طـلاق مراجعه كنتده به دادكاه خانو اده شهيد محلاتى شهر تهران بود. از بين اين متقاضيان تعداد نمونسه هابل نفـر بـه روش نمونسه

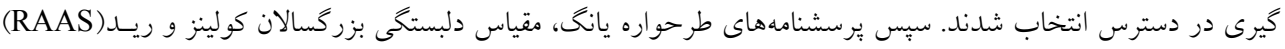
و مقياس رضايت زناشويى اينريج توسط شركت كنندگان تكميل شد و براى تجزيه و تحليل دادهها از ركرسيون گام به خـام استفاده گرديد. يافته ها: نتايج نشان داد بين مؤلفههاى دلبستخى (اضطراب و نزديكى) و رضايت زناشويى رابطه منفى معنادار وجــود دارد و اين دو متغير مجموعا كا درصد از واريانس رضايت زناشويى را تبيين نمودند. همجنين بين وابستخى و رضايت زناشـويى رابطه معنىدارى يافت نشد. علاوه بر اين بين رضايت زناشويى و مؤلفههاى طرحوارههاى ناساز گار اوليسه شـامل اطاعـت، شكست، نقص، خودتحول نيافته، خويشتن دارى، انزواى اجتماعى، ايثار، رهاشدكى و استحقاق رابطـه منفى و معنـادارى وجود دارد و به طور كلى اين متغيرها توانستند سع درصد از واريانس رضايت زناشويى را تبيين نمايند. همجنين متغيرهاى بيىاعتمادى، بازدارى هيجانى و معيارهاى سرسختانه نقش معنى دارى در بيشبينى رضايت زناشويى نداشتند. نتيجه گيرى: نتايج يزو هش حاضر نشان مىدهد كه طرحوارههاى ناساز خار اوليه نسبت به مؤلفه هاى دلبستخى نقش بيشـترى در تبيين واريانس رضايت زناشويى داشتهاند. كلمات كليدى: طرحوارههاى ناساز گار اوليه، دلبستخى، رضايت زناشويى

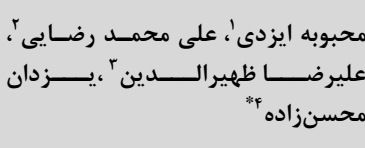

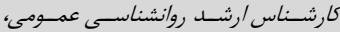

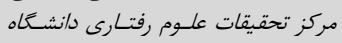

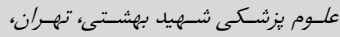
ايران استاديار،كروه روانشناسى بالينى دانشكاه سمنان، سمنان، ايران

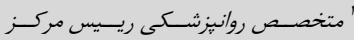

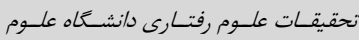

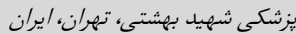

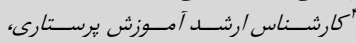

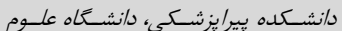
يزشكى البرز، كرج، ايران

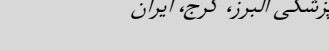

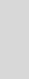


كـه در سـلامت روانـى زوجـين و فرزنسدان آنهـا دارد، اجتنــاب

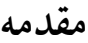

نايذيراست.

عوامل بسيارى در رابطه زناشويى مؤثر هستندكه عوامل شناختى

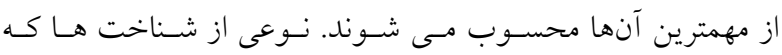

دررابطه زناشويى نقش مهمى به عهلده دارند، طرحسو اره هـا هسـتند. طرحواره ها سازه هايى هستند كه بر اساس واقعيت يا تجربه شـكل فئل مى گيرند و به عنوان واسطه، پِاسخ هاى رفتارى افراد را تحت تـأثير قرار مى دهند. يانخ (1999) بر اين باور است كـهـ طرحسو ارههـا در

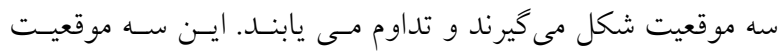

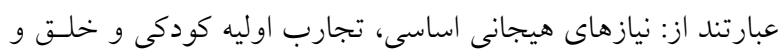
خوى هيجانى. ريشههاى تحولى طرحوارههاى ناساز گارانه اوليه در تجارب ناگوار دوران كودكى نهفته است، طرحوارههايى كـه زودتـــ شكل مى گيرند، معمولاً قويتر هستند. برخى از طرحواره ها به ويـزّه

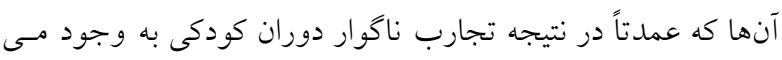

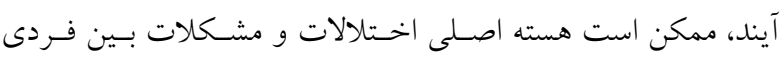
باشند. طرحوارهها موجب سو كيرى در تفسيرهاى مـا از رويــادها مىشوند و اين سو گيرىها درآسيبشناسى روانى ميان فـردى خـود

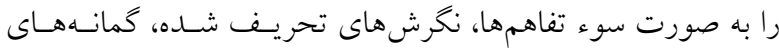

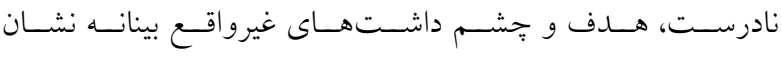
مى دهند. يانگ و كلوسكس(199V)، اشاره كردند كه رضـايت در روابـط نزديك فقط زمانى ديده مى شود كه نيازهاى رشدى بــر آورده شـده باشند و اخر اين نيازها ارضا نشـوند ممكـن اسـت طرحسواره هـاى ناساز گار خاصى ايجاد شوند كه بر روابط صميمانه اثر مسى كذارنـد.

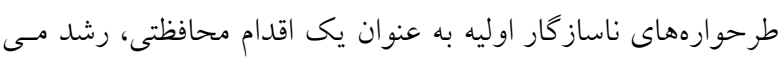
كنند و به خدمت يك هدف كاركردى در مى آيند. مشـكل از آنجـا آغاز مى شود كه اين طرحواره ها تا دوران بزرگسالى ادامه بيدا كنند و تاثير نامطلوبى بر زندكى و يا روابـط برجـاى بحـــارد. طرحسواره

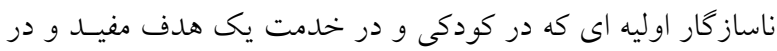

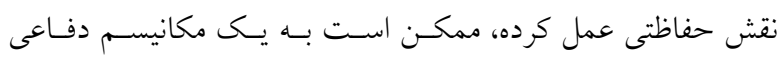

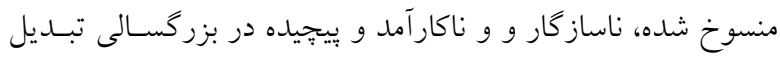

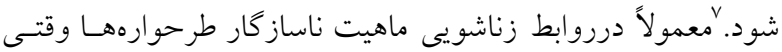

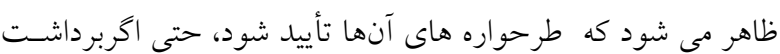

ازدواج در جامعهُ متغير امروزى يك يديده بِيجِيده اسـت. ازدواج يكى از مهمترين شكل هاى حمايت اجتمـاعى بــراى بزر گسـالان در نظر گرفته شــه اسـت و براسـاس يافتـه هـاى حاصـل از مطالعـات

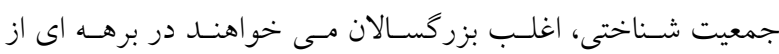

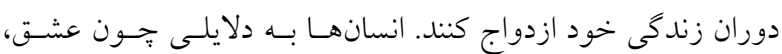
امنيت اقتصادى، محافظت، امنيت عاطفى، احساس آرامـش و فــراراز تنهايى ازدواج مسى كنـــــدر واقـع، ازدواج مؤفـق و شـروع رابطـه. زناشويى قادر است بسيارى از نيازهاى روانسى و جسـمى رادر يـى

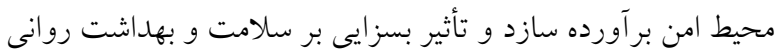

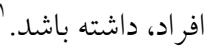
سازمان جهانى بهداشت نيز خانواده را به عنوان عامل اجتمـاعى بـى اوليه در افزايش سلامت و بهزيستى معرفى كـرده اسـت. از ايسنرو

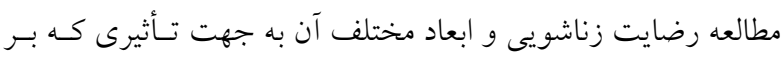
بهداشت روانى افراد دارد، از اهميت زيادى برخوردار است. رابطه زناشويى به عنوان مهمترين و اساسى تـرين رابطـهـ انسـان

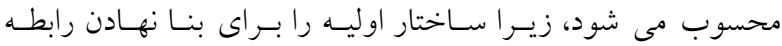

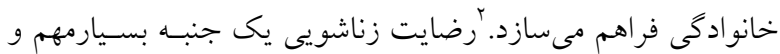
بيجيده از يك رابطه زناشويى است به عبارت ديخر ، يكسى از جنبـه

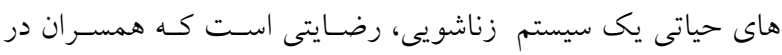
رابطه خويش احساس و تجربه مى كنند، توافـق زيـادى بـا يكـديخر دارند، از نوع و سطح روابطشان راضىاند. بَه عبارت ديخر، اصطلاح رضايت زناشويى به مسرت كلى شـخص و خشـنودى او از روابـط نزديك زناشويى اشاره دارد. با وجود مزاياى ازدواج، ميزان طلاق از

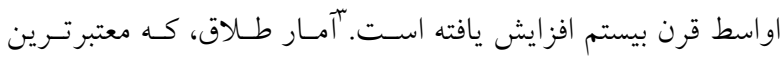
شاخص آشفتخى زناشـويى اسـت، نشـانكر آن اسـت كـه رضـايت زناشويى به آسانى قابل دستيابى نيست. أز همـان روزهـاى آغـازين رابطه زناشويى، به دليل حل نشدن عدم توافقهـاى جــى و مكـرر

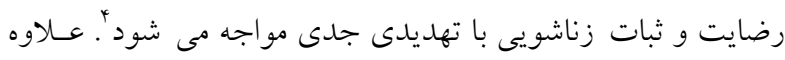
براين، برخلاف برخى روابط زناشويى كه به طلاق ختم مسى شـوند،

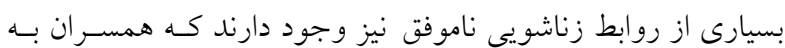

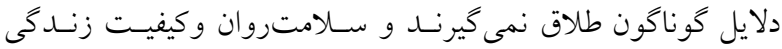
طرفين به خطر مىافتد. لذا توجه به رضايت زناشويى به خاطرنقشى 


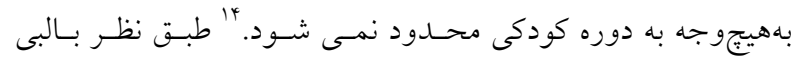

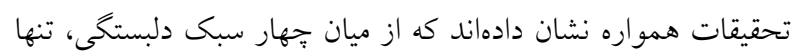

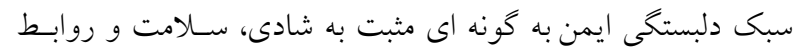

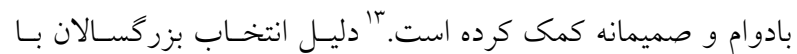

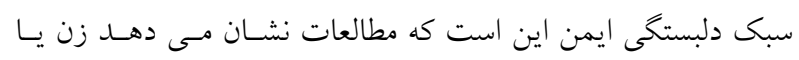

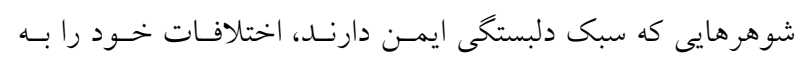

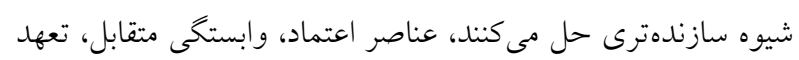
و رضايت، در روابط آن ها بيشتر به جشـم مسى خـورد و روابط و

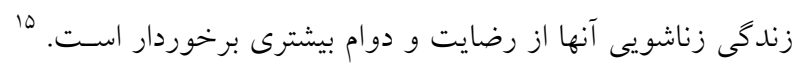

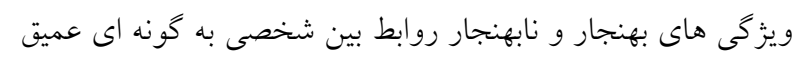

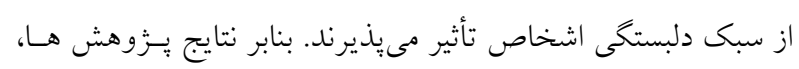

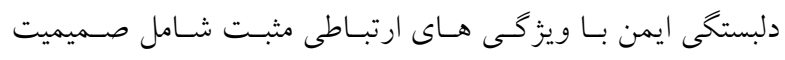

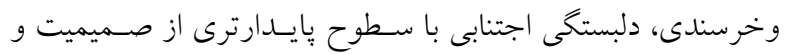

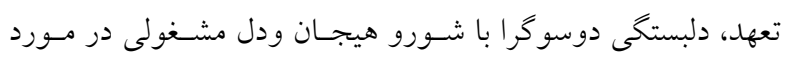
روابط توأم با خرسندى كم مرتبط است. 10

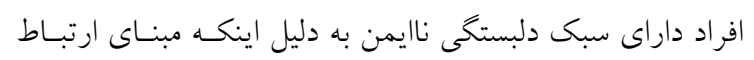

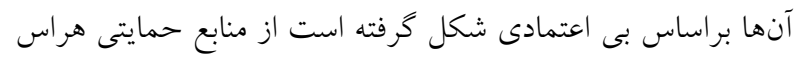

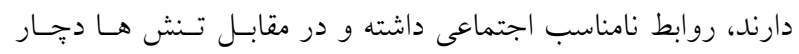

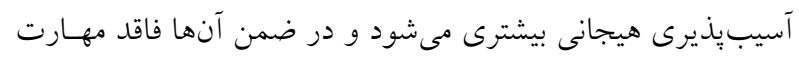

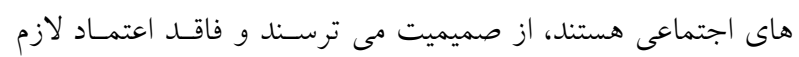
براى برقرارى روابط صميمانه هستند. 19

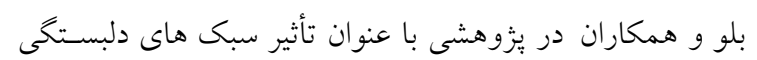

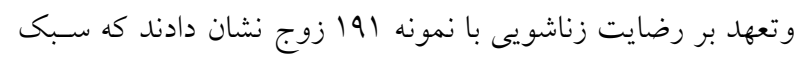

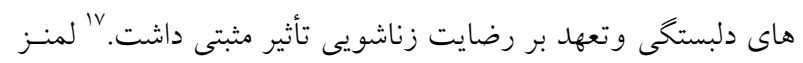

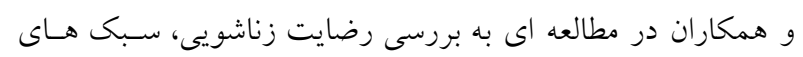

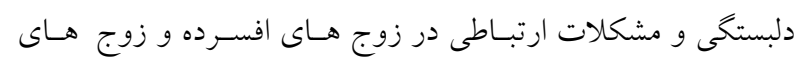

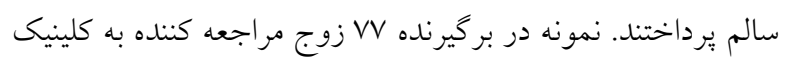

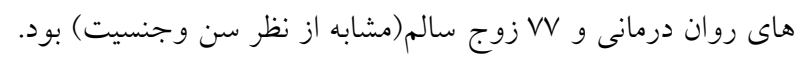

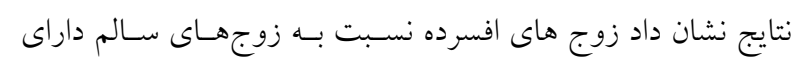

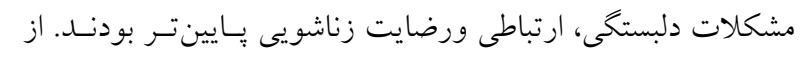

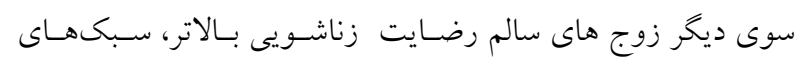

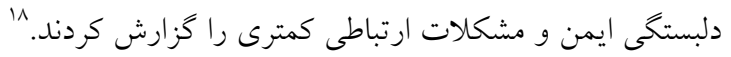

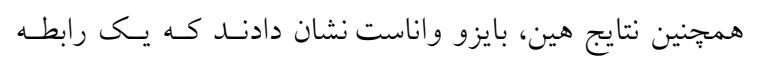

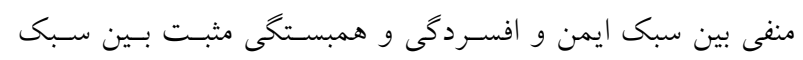

اوليه آنها نادرست باشد.؛. اكرافرادى كه در يكى رابطه معسين ماننـــ

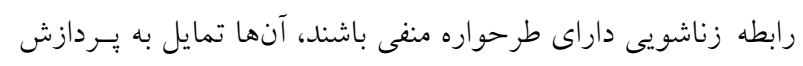

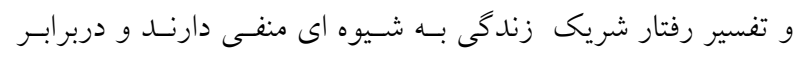

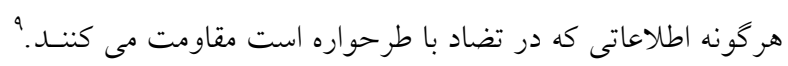

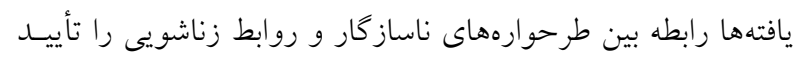

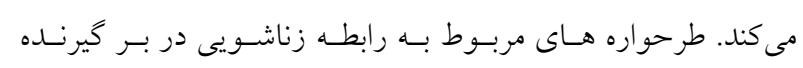

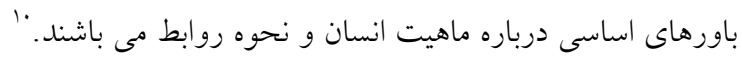

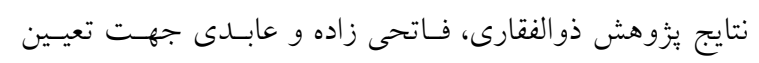

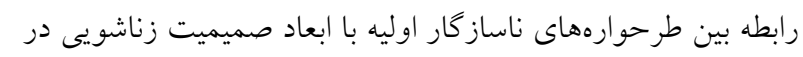

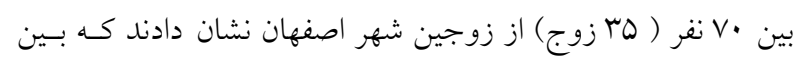

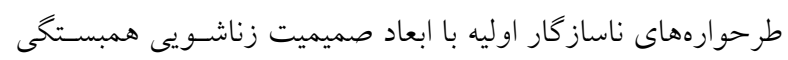

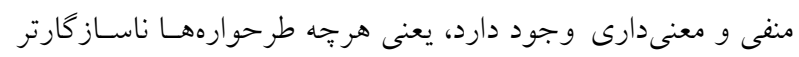
مىشوند، صميميت زناشويى كاهش مى يابد.

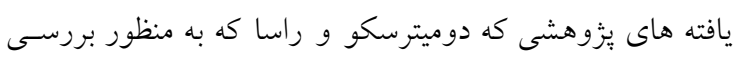

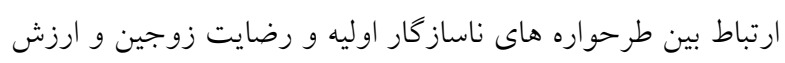

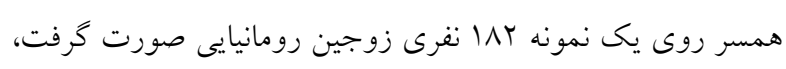

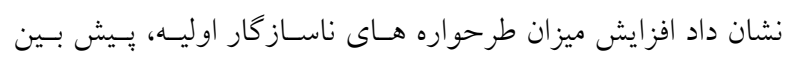

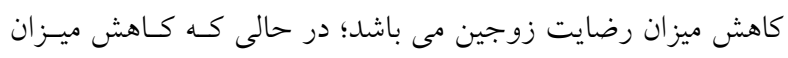

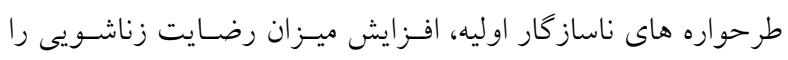
بيش بينى مى كند.

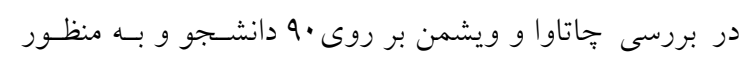

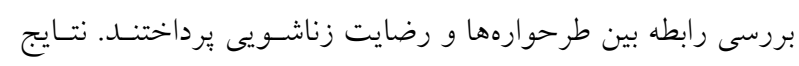

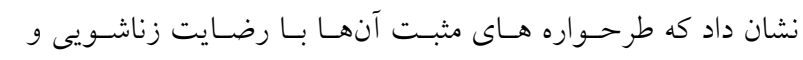

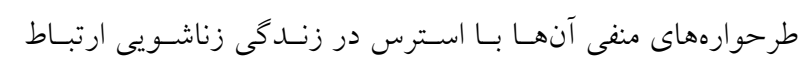
داشت.

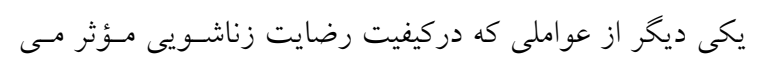

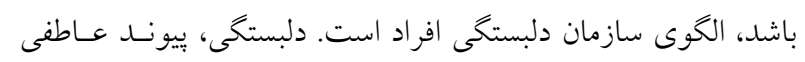

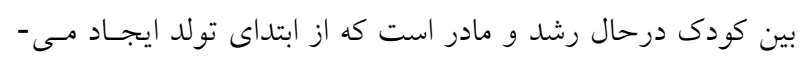

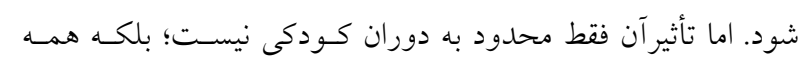

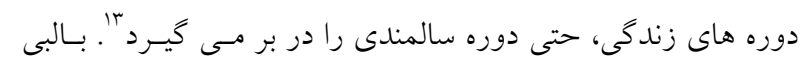

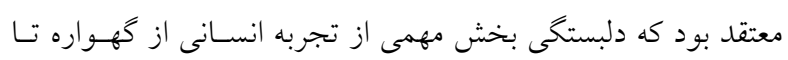

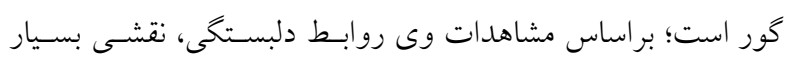

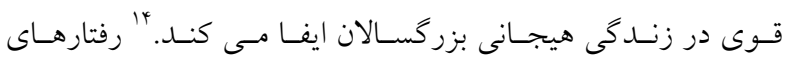

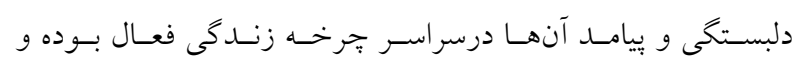


همكاران (IrAV )، روايى و وِايايى ير سشنامه طرحواره هاى ناساز كار

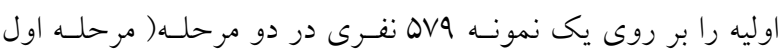

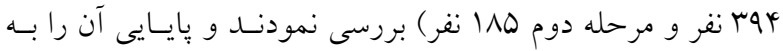

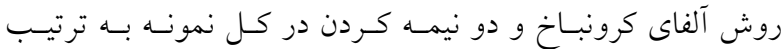

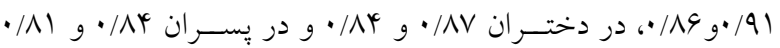

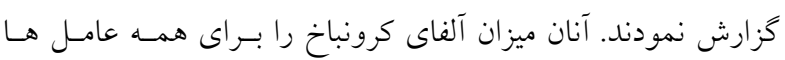

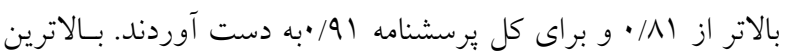

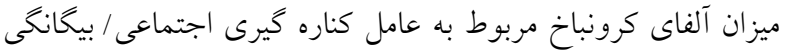

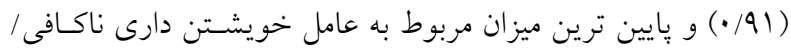

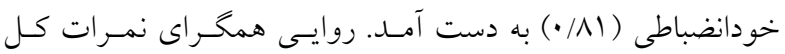

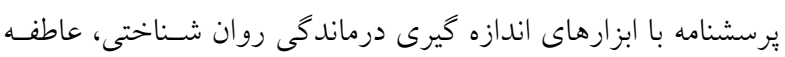

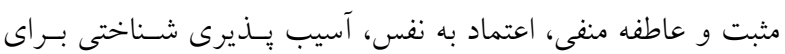

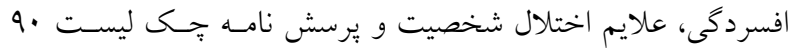

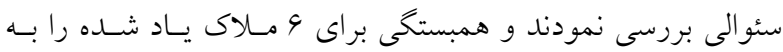
ترتيـب V

نمودند.

\section{يرسشنامه مقياس دلبستخى بزرخسالان كولينز و ريد (RAAS)}

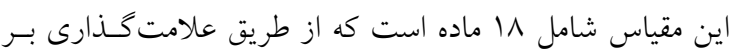

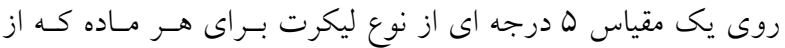

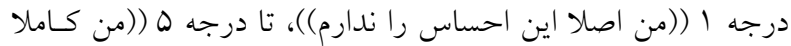

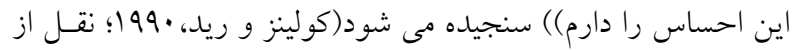

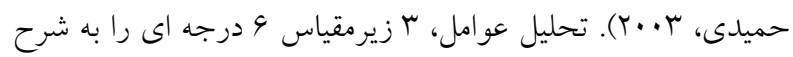

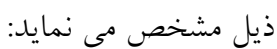
ا. نزديكى و صسميميت: ميـزان آسـايش در رابطسه بـا صـميميت و نزديكى هيجانى را اندازهكيرى مى كند.

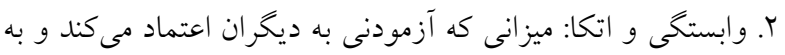

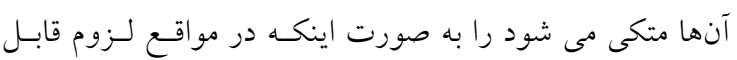
دسترسى اند، اندازه كيرى مى كند.

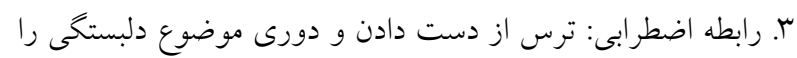

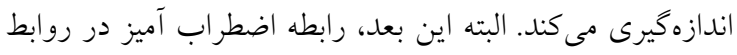

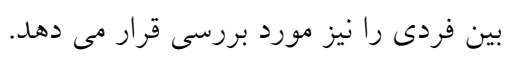

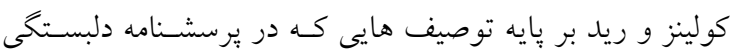

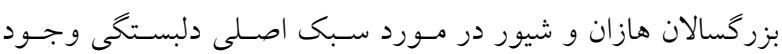

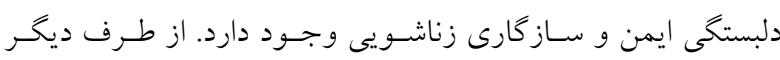

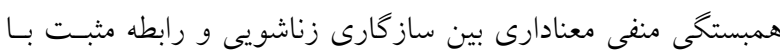

$$
\text { افسردكى وجود دارد. } 19
$$

در يزوهشى كه بهمنظـور بررسى رابطـهى بـين طرحسوارهــاى ناساز گار اوليه و دلبستى بزرگسالى انجام گرفت، نتايج نشان دادند

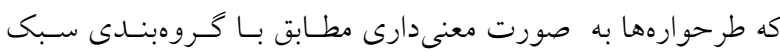

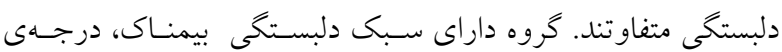
بيشترى از طرحوارههاى ناسـاز كار را داشـتند كـه بـه وسـيله كَروه

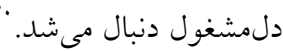
در همين راستا، اين يُزوهش با هدف تعيين رابطه طرحوارههاى

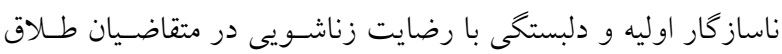

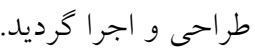

مواد و روشها - ماد

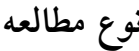
يزّوهش حاضر از نوع تحقيقات همبستى مىباشد.

\section{روش جمع آورى اطلاعات}

يرسشنامه طرحواره يانغ: شكل كوتاه برسشنامه طرحسوارههـــ

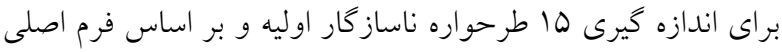

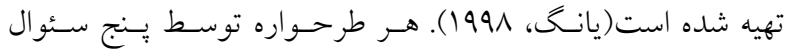

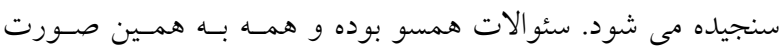

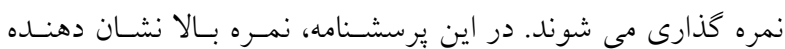

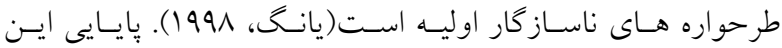

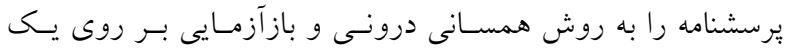

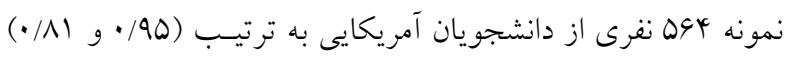

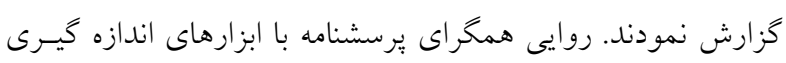

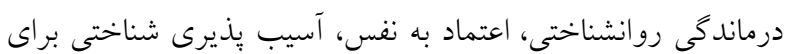
افسردگى و علايم اختلال شخصيت بررسى شده است. نتايج حاكى

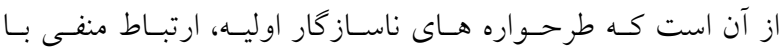

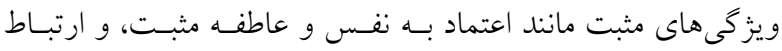

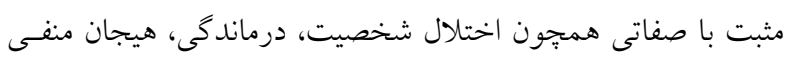

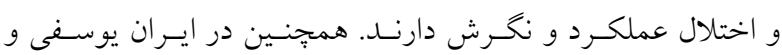


هائوال و كا ا خرده مقياس تشكيل شده است. باسخ به سئوالات

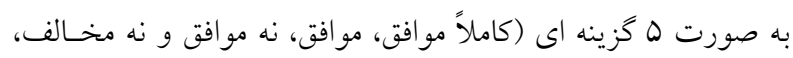

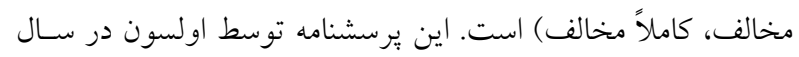
س1911 براى ارزيابى زمينههاى بالقوه مشكلزا و شناسايى نقاط قوت

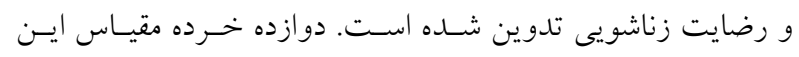

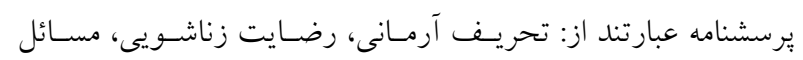

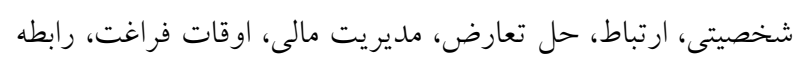
جنسى، فرزندان، نقشهـاى مسـاوات طلبس، خـانو اده و دوسـتان و و

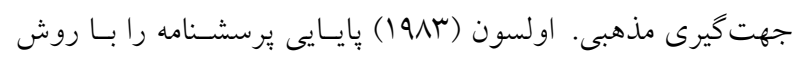

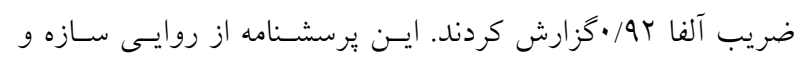
ملاك خوبى برخوردار است. همجنين كليه خرده مقيـاس هـاى ايسن

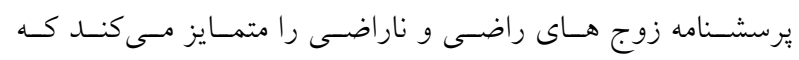

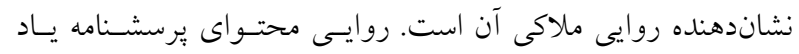
شده نيز توسط ينج نفر از استادان روانشناسى و متخصصان مشـاوره

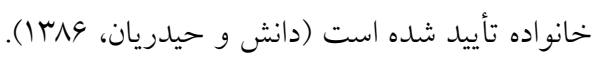

\section{روش كار}

يّ از كسب مجوزهاى لازم محقق بـه دادكـاه خـانو اده شهيد

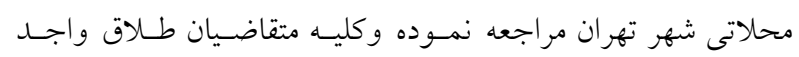

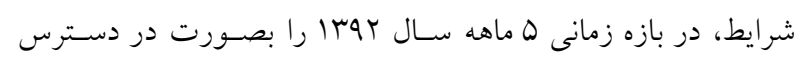

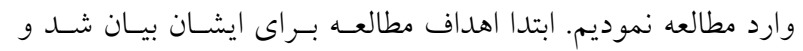

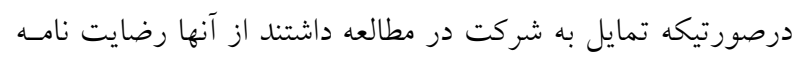
كتبى كرفته شد. معيارورود عبارت بود از: ايرانى بودن و حداقل سواد خواندن و

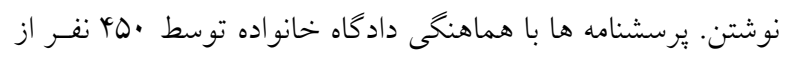

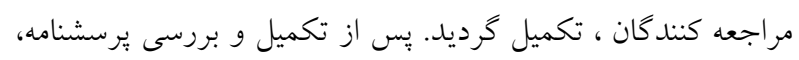
اطلاعات با نرم افزار وspss أتحليل خرديد.

\section{يافته ها}

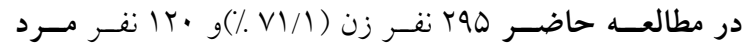
( \% Y Y/Q )

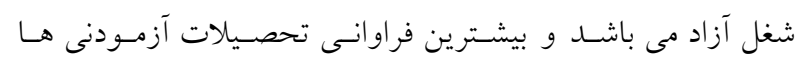

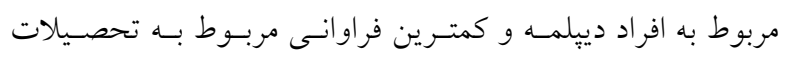

داشت مواد يرسشنامه خود را تدارى ديده اند. زيرمقياس اضطراب

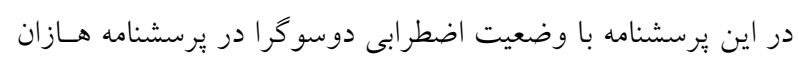

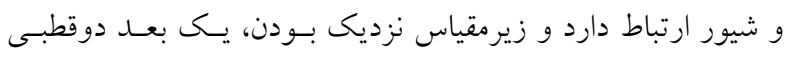
است كه اساساً توصيف هاى ايمن و اجتنابى را در مقابـل هــم قـرار

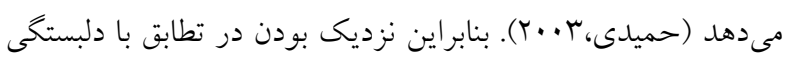
ايمنى بخش (S) مى باشد و زيرمقياس وابستخى را مسىتسوان تقريبـاً عكس دلبستخى اجتنابى (Av) قرار داد. مطالعات نشان دادند كـه زيرمقيـاس هـاى نزديـك بـودن (C)، و ابستخى(D) و اضطراب (A) در فاصله زمانى ب و حتى ^ ماه يايدار

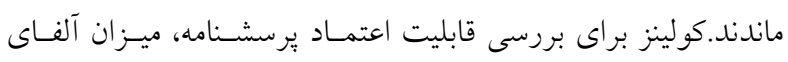

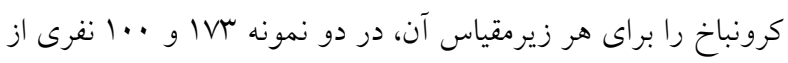

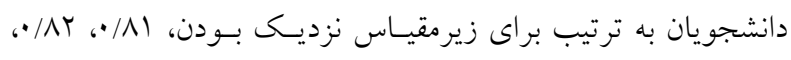

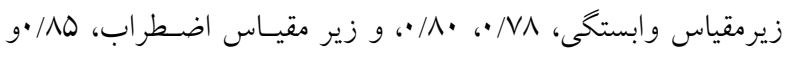

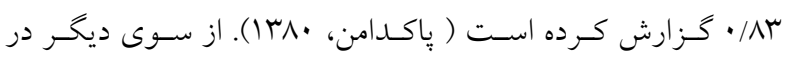

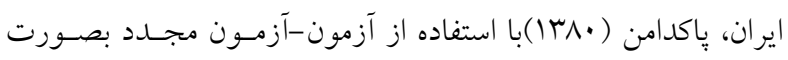

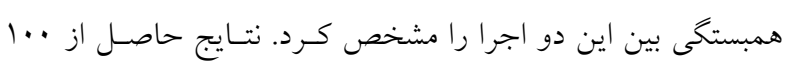
نفر دختر و يسر در دوبار اجرا به فاصله زمانى يكى ماه بيانگر آن بود

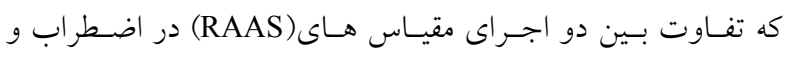

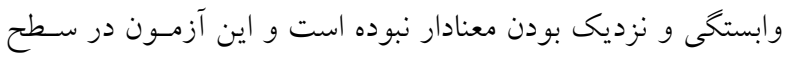

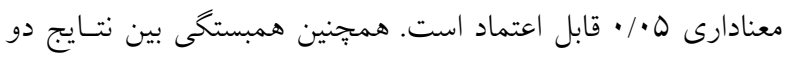

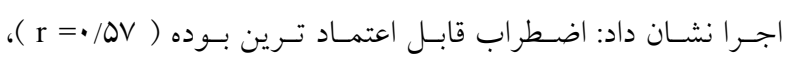

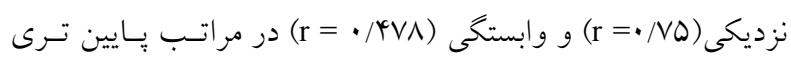
هستند. از سوى ديخر با محاسبه آلفاى كرونباخ مشخص كرديد كـهـ

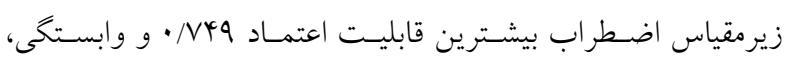

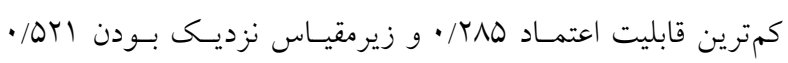

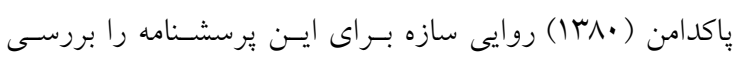

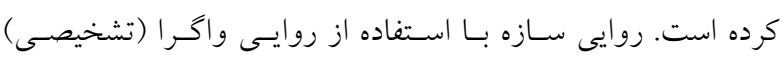

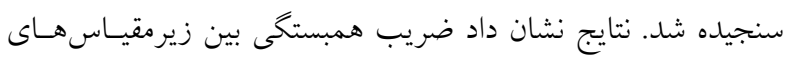

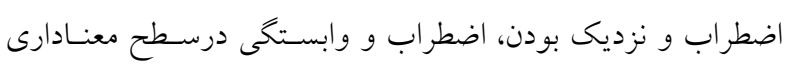

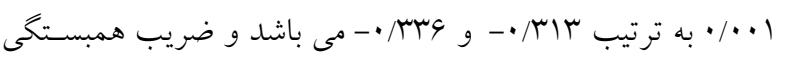

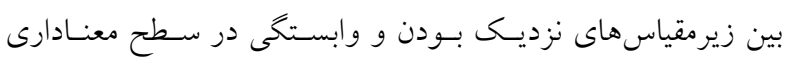

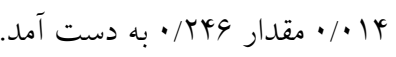

مقياس رضايت زناشويى اينريج : فرم اصلى اين برسشـنامه از 
نظر سطح دلبستخى ميانخين نمرات آزمودنى ها در نزديكى (19/91) ليسانس و بـالاتر مسىباشــ (جــول (1). براسـاس نتـايج بيشـترين

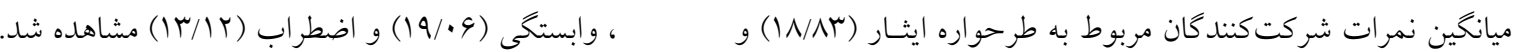

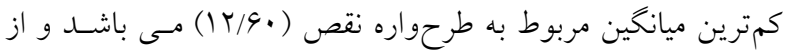

\begin{tabular}{|c|c|c|c|}
\hline درصد فراوانى & فراوانى & \multicolumn{2}{|c|}{ اطلاعات دموگر افيك } \\
\hline$V M / 1$ & r90 & 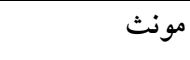 & جنس \\
\hline TN/q & ir. & مذكر & \\
\hline 1 & r & بيسو اد & تحصيلات \\
\hline$|V /|$ & VI & زيردييلم & \\
\hline $90 / 1$ & $r V r$ & دييلم & \\
\hline $10 / V$ & 90 & ليسانس و بالاتر & \\
\hline $1 / 4$ & 4 & كزارش نشده ها & \\
\hline$V Q / V$ & MIF & آزاد & 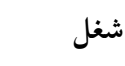 \\
\hline$r M / 4$ & 19 & 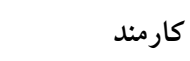 & \\
\hline$r / 9$ & ir & بيكار & \\
\hline
\end{tabular}

جدول جي: ميانخين و انحراف معيار نمرههاى آزمودنى ها در متغيرهاى طرحوارههاى ناساز گارانه اوليه و سبك دلبستخى

\begin{tabular}{|c|c|c|c|}
\hline انحر اف استاندارد & ميانخين & شاخص آمارى & متغير \\
\hline$\psi / \mu \wedge$ & $19 / V 9$ & محروميت هيجانى & \\
\hline$r / v \cdot$ & $19 / 91$ & رهاشدگى & \\
\hline r/vA & $19 / 44$ & بى اعتمادى & \\
\hline$Y / T Q$ & $1 \% / T Q$ & انزوا ان & \\
\hline$r / \cdot r$ & $1 Y / 9$ & نقص & \\
\hline r/T & $\mid x / 44$ & 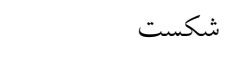 & \\
\hline ऍ/A & $1 \% / 94$ & بى كفايتى & \\
\hline$r / 9 \mathrm{~V}$ & $19 / \mathrm{V}$ & آسيب به ضرر & طرحواره هاى ناساز كار اوليه \\
\hline$r / 90$ & $10 / \cdot 0$ & خودتحول نيافته & \\
\hline$r / 4 \Lambda$ & $10 / \lambda Y^{K}$ & اطاعت & \\
\hline $4 / \cdot 9$ & IN/Ar & ايثار & \\
\hline$r / T$ & $19 / 0 r$ & بازدارى هيجانى & \\
\hline$r / N$ & $\mid V / D \Lambda$ & معيارهاى سرسختانه & \\
\hline r/ck & $191 \cdot V$ & استحقاق & \\
\hline$r / \cdot r$ & $19 / \pi 1$ & خويشتن دارى & \\
\hline$r / 0$. & $19 / 91$ & نزديكى & \\
\hline$r, \mu Y$ & $19 / .9$ & و وابستخى & سبك دلبستخى \\
\hline Q/9V & $1 r / 1 r$ & اضطراب & \\
\hline $\mid Y N / T)$ & $r Y / 119$ & رضايت زناشويى & رضايت زناشويى \\
\hline
\end{tabular}


جدولץ: ارتباط متغير رضايت زناشويى با طرحوارههاى ناساز گار اوليه و مؤلفه هاى دلبستىى در بين شركت كنند كان در مطالعه

\begin{tabular}{|c|c|c|c|c|c|c|}
\hline سطح معنى دارى & $T$ & & ${ }^{r} \mathbf{R}$ & $\mathbf{R}$ & متغيرهاى بيشبين & كام \\
\hline.$/ .1$ & $19 / 4 r$ & &.$/ 199$ &.$/ 411$ & & ثابت \\
\hline 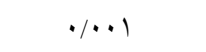 & $-\Delta / 4$ & $-\cdot / T V Q$ & .1199 &.$/ 411$ & اطاعت & 1 \\
\hline$\% \cdot \cdot 1$ & $-1 \cdot / 40$ & - ./ATV & . Mat &.$/ 014$ & شكست & r \\
\hline 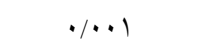 & $-\Lambda / v 9$ & $-\cdot / r q r$ & $\cdot \pi r$. & $\cdot 1090$ & اضطراب & $r$ \\
\hline$\% \cdot 1$ & $-N / F r$ & - & $\cdot \pi \wedge 1$ &.$/ 91 V$ & نزديكى & r \\
\hline$\%$ & $-\varphi / \Delta \varphi$ & $-\cdot /$ MY & . & .1990 & نقص & 0 \\
\hline$\% \cdot \cdot 1$ & $-9 / 04$ & $-\cdot / r q 4$ & . / YVO &.$/ 99$ & خود تحول نيافته & 4 \\
\hline.$/ \cdot 1$ & $-r / 99$ &.$- / 194$ & $\cdot / 0 \cdot 4$ & $\cdot N I \cdot$ & خويشتن دارى & v \\
\hline$\% \cdot \cdot 1$ & $-r / V Y$ & $-\cdot / 194$ & . $/$ QYY & - NYY & انزواى اجتماعى & $\wedge$ \\
\hline$\% \cdot \cdot 1$ & - & $-\cdot / 1 \Gamma$ & 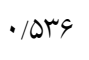 & • NRr & ايثار & 9 \\
\hline.$/ \cdot 1$ & $-r / q r$ &.$- / 119$ & $\cdot / D K Y$ & $\cdot N r V$ & رهاشدكى & 1. \\
\hline 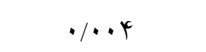 & $-r / \Psi \wedge$ & $-\cdot / 1 \cdot r$ & $\cdot / \Delta Q 1$ & - NAY & استحقاق & \\
\hline
\end{tabular}

ناساز كار رابطه معنادار دارند. همانكونه كه مشاهده مى شود مؤلفـهـ-

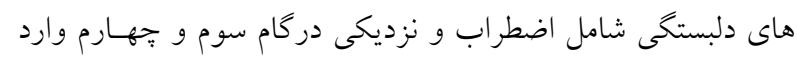

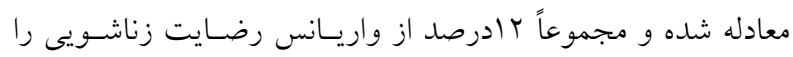

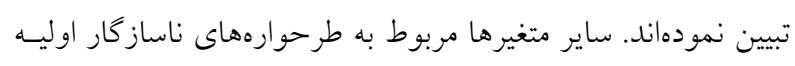

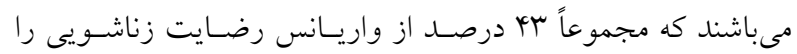

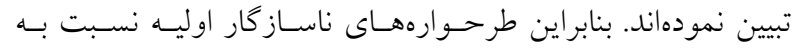
مؤلفـهــاى دلبستخىى سهم بيشـترى در تبيسين واريـانس رضـايت

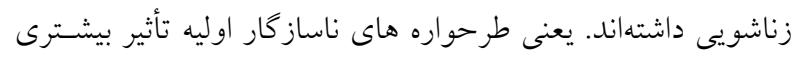

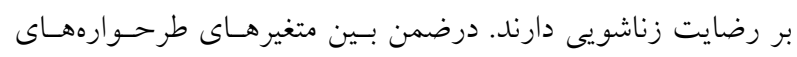

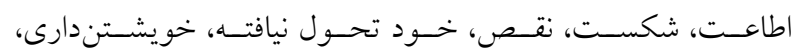

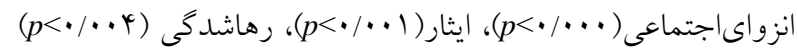

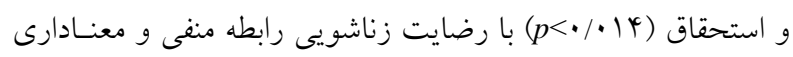

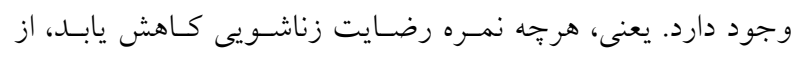

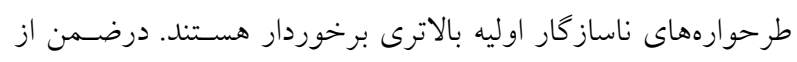

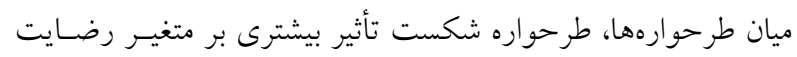
زناشويى دارد. زيرا داراى بتا و تى بزركتر و سطعح معنـادارى كمتـر

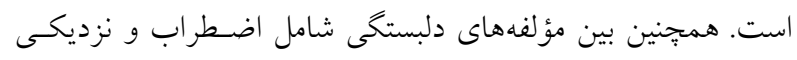

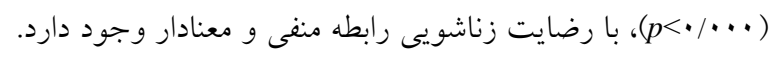

ييش از استفاده از تحليل ركرسـيون در ابتـا وجـود داده هـاى

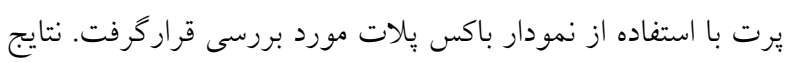

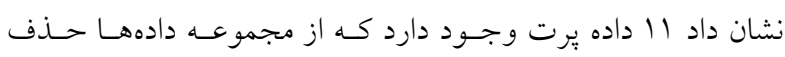

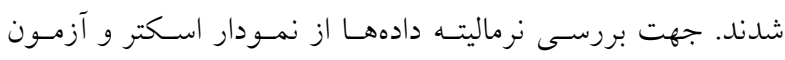

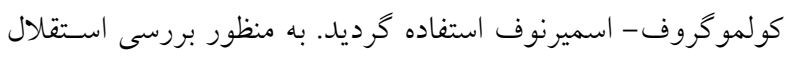

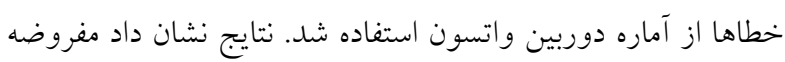

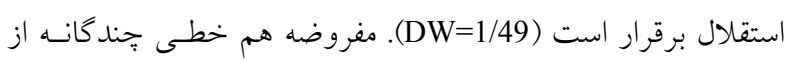

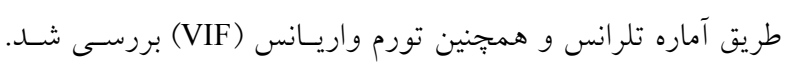

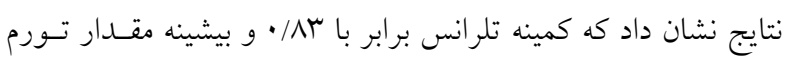

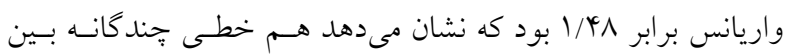

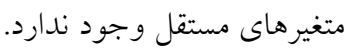
نتايج مدل ركرسيون كام به كام بيانكر اين مطلب بود كه در كام مام مارد

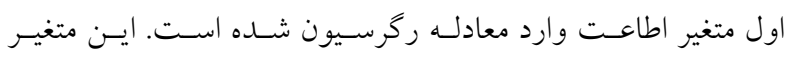

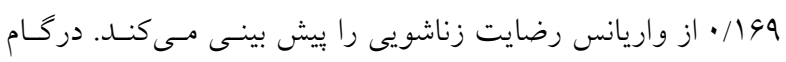

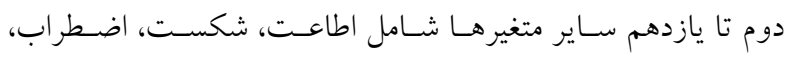

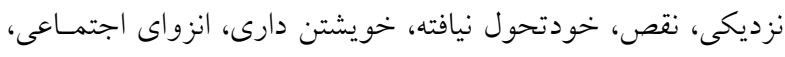

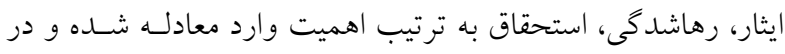

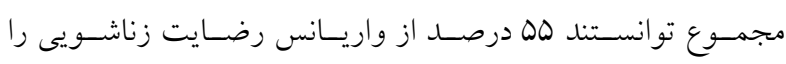

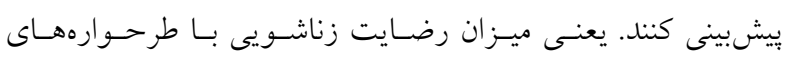


اين احساس را داشته باشند كه از جانب شريك زندكى شان، عشـقى

را كه سزاوارش هستند دريافت نمى كنند و ممكـن اسـت احسـاس بىارزشى كنند (محروميـت هيجـانى، نقـص). آنهـا ممكـن اسـت احساس انزوا و متفاوت بودن نسـبت بـه همسرشـان داشـته باشــند

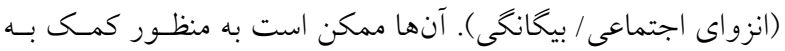

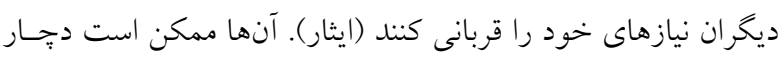
ناتوانى از تحمل هرگونه ناكامى در راه رسيدن به اهداف و همجِنين در مهار و بيان انخيزهها يا احساساتشان باشند (خويشتندارى). آنها ممكن است احساس كنند نسبت به ديخران يك سـر وكـردن بـالاتر هستند و تعهلى نسبت به رعايت اصول روابط متقابل كـه راهنمـاى تعاملات اجتماعى بهنجار هستند، نداشته باشــند (اسـتحقاق). آنهـا

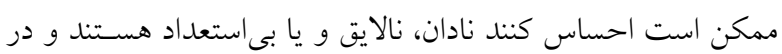
نتيجه تلاشى براى بهبود روابط خود نمى كنند، جون باور دارند كـه

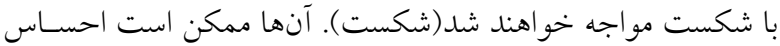
كنند وجودشان در ديخران ادغام شده و هويت جداگانه اي ندارنـد. اين طرحواره اغلب به صورت احساس بوجى و سردر گمى، جهـت

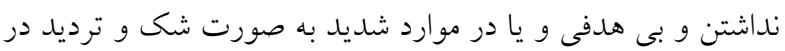
موجوديت و ساختار وجودى فرد بروز مى كند(خـود تحـول نيافتـه/

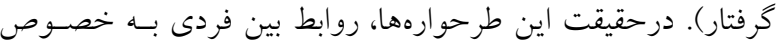
روابط زن و شوهر را مختل مى كنـــ و موجــب ناخشـنودى و عــدم كيفيت رضايت زناشويى مى شـود. زيــرا طرحسو اره هــاى ناسـاز كار مداوم در مسير زندگى موجسب سو گيرىهايى در تفسير رويدادها و تجارب افراد مىشوند. اين سو گيرىها بـه صـورت سـوءتفاهمهـــا، نحــش هـاى تحريف شده، فرضهاى نادرست، هدفها و نيازهـاى

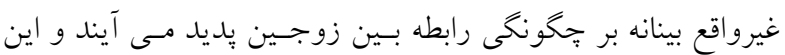

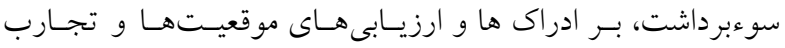

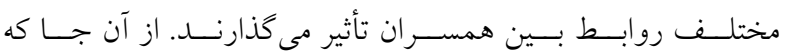

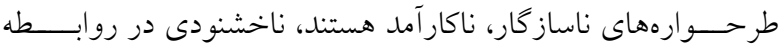

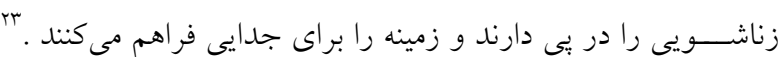

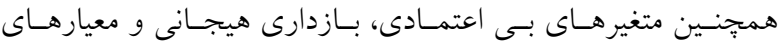
سرسختانه نقش معنى دارى در بيش بينى رضايت زناشويى نداشـتند

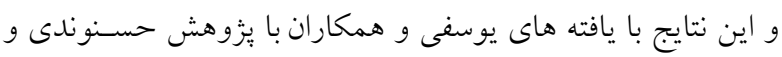

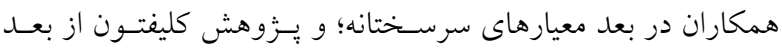

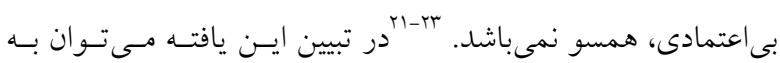

هدف از انجام يزوهش تعيين رابطه طرحوارههاى ناساز گار اوليه

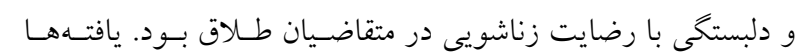
نشان داد از بين طرحوارههاى ناساز گار اوليه، طرحوارههاى اطاعـ، شكست، نقص، خودتحول نيافته، خويشتندارى، انـزواى اجتمـاعى، ايثار، رهاشدگى و استحقاق بيش از ساير طرحسـوارههـا بـا رضـايت

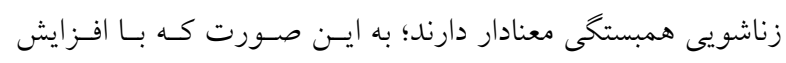

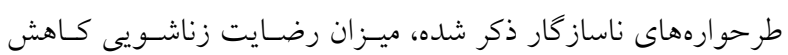

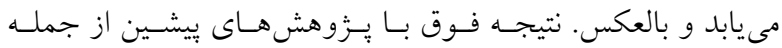

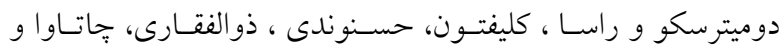

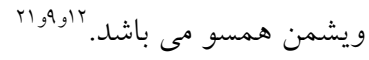

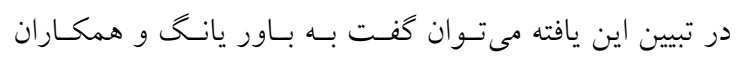

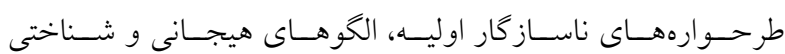
خودشكنندهاى كه در جريان رشـد و تحـول آغـاز مسى گردنـد و در سرتاسر زندگى تكرار مىشوند. از سوى ديخر، آسيبشناسى روانس فرد مى تواند، بازتاب طرحسوارههــاى ناكارامـــ وى باشـــ، بنـابراين،

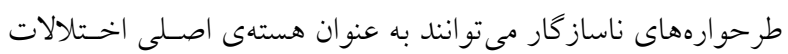

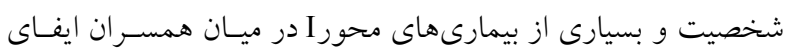
نقش كنند. افراد مبتلا به طرحواره رها شـدگى، فكـر مسى كنندكسى كـه از لحاظ عاطفى به او دلبسته شدهاند را از دست مى دهنـــ و معتقدنـــ

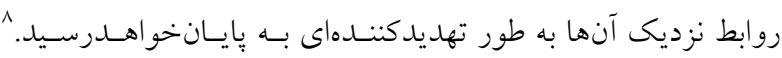

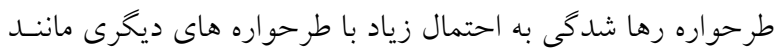
طر حواره اطاعت ارتباط بيدا مى كنند. در جنين وضعيتى، فرد معتقد است اگر كارهايى را كه ديخران از او مى خواهند انجام ندهد، بدون

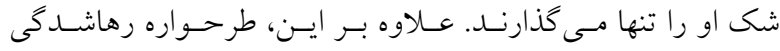
مى تواند با طرحواره نقص ارتباط بيدا كنـــ. در جنسين حسالتى، فـرد

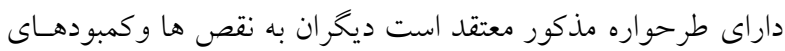
او بيى مىبرند و او را ترك مى كنند.بر اساس اين نتايج ما مىتوانيم

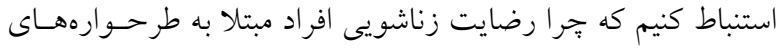

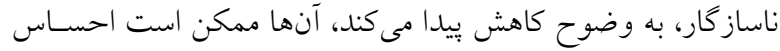
كنند كه همسرشان نمى توانـد محافظـت و حمايـت عـاطفى لازم را براى آنها فراهم نمايد. همجنين ممكن است بـهـ ايسن بـاور رسـيده

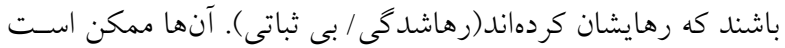


مسى خواهنـــ كـه بيشـتر شـريك احساساتشـان شـوند. بزركسـالان

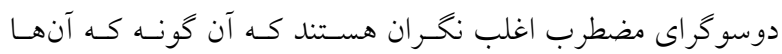

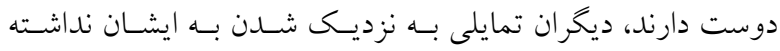
باشند. بزر كسالان دوسو كراى مضطرب معمولاً تمايل دارند به طسور

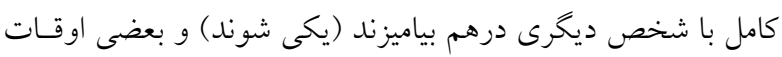

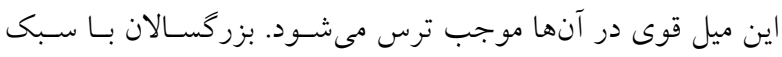

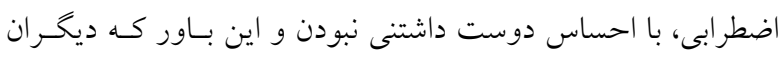

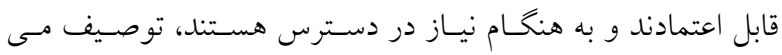
شوند. طبق يافتههاى اين يزووهش، مؤلفه اضطراب قوىتـرين مولفـهـ

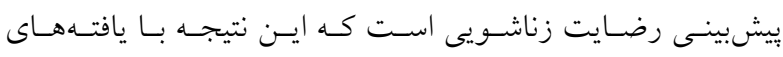

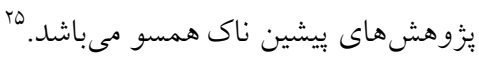

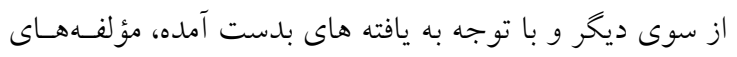

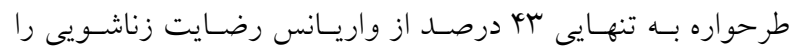

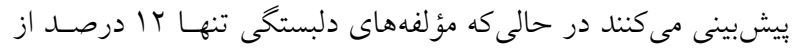

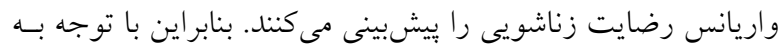

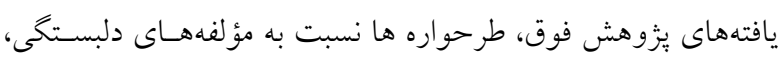

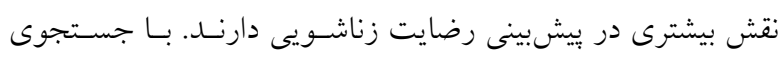

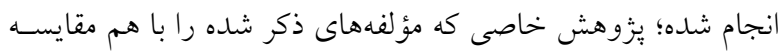

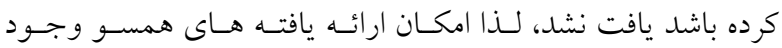

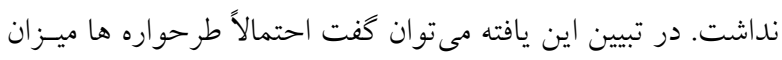

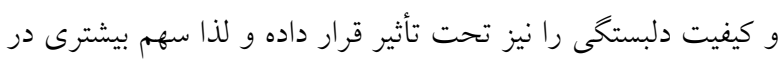

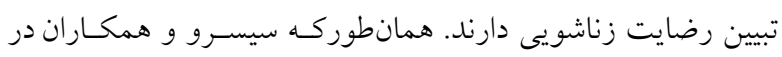

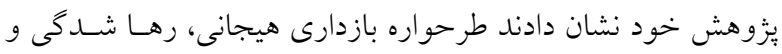
محروميت هيجسانى در بزر كسـالى دلبستخى ايمـن را بـه مخـاطره

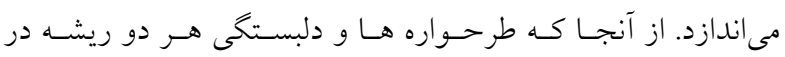

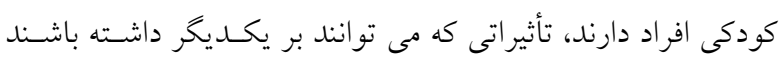
دور از انتظار نخواهد بود.

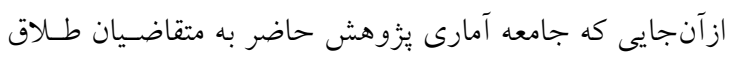
محدود مى شود، اين موضوع مى تو اند محدوديت هايى را در زمينه

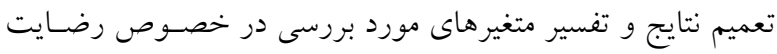

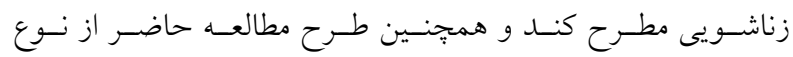

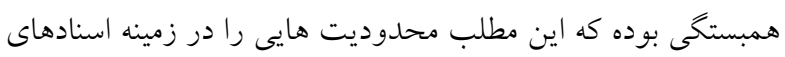
علت شناختى متغيرهاى مورد بررسى مطرح مى كند كه بايد در نظر

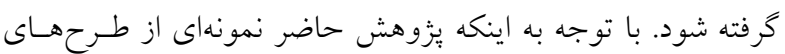

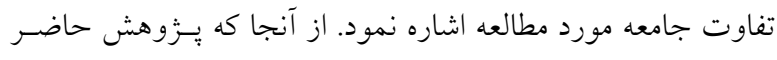

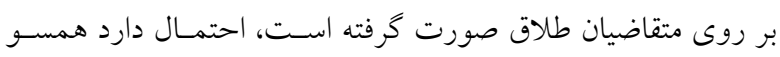

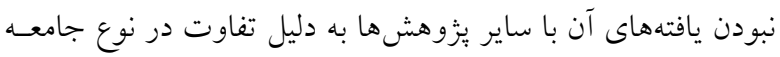

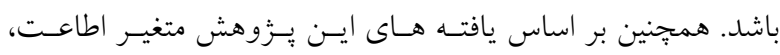

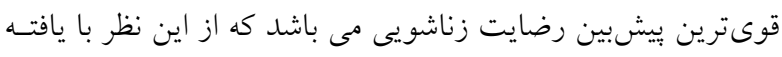

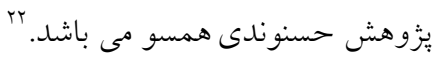

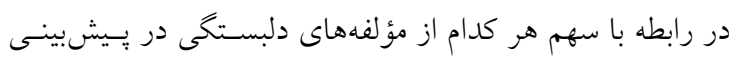

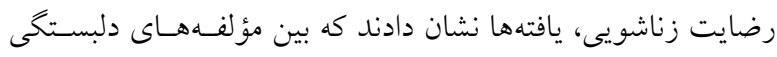

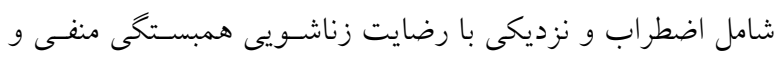

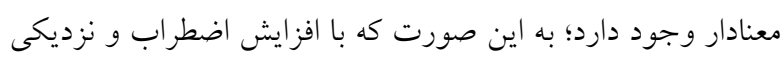
ميزان رضايت زناشويى كاهش مى يابد و بالعكس.

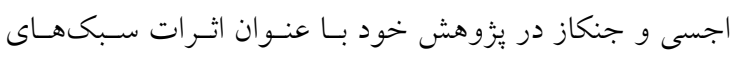
دلبستىى، مهارت هاى حل مسأله و مهارتهاى ارتباطى در رضايت

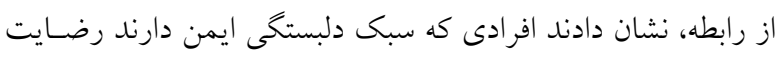

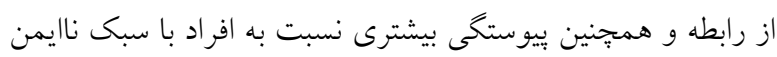
دارند.

در تبيين اين يافته مى توان كفت مطابق با ديدكاه بالبى، سيستم

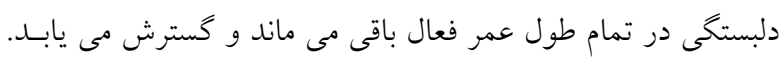

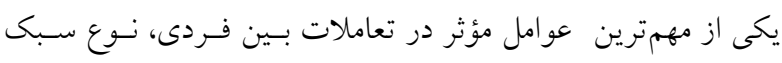

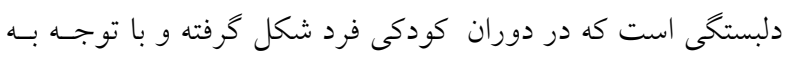

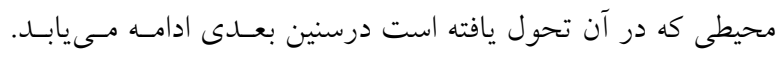

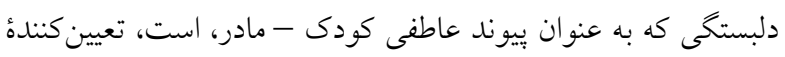

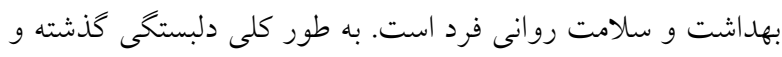

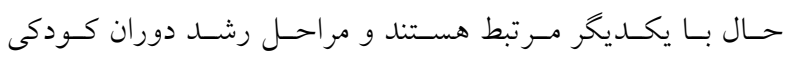
بهخصوص روابط اوليه فرد با والدين بر روابط زناشويى تـأثير دارد.

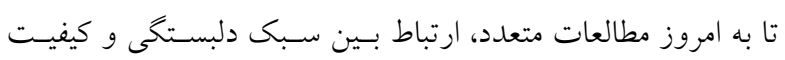

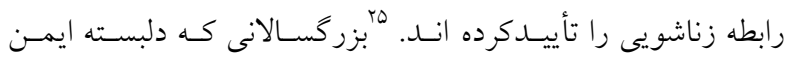

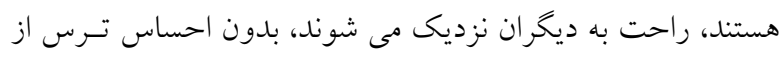

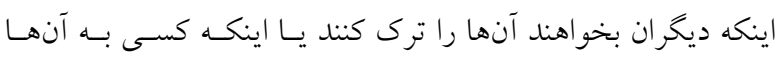

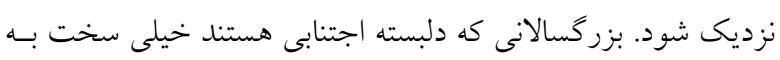

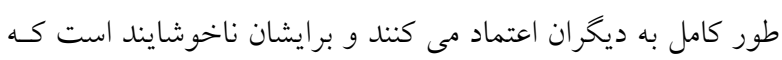

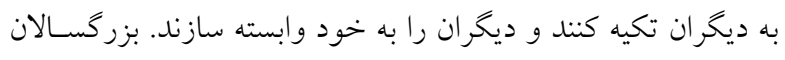

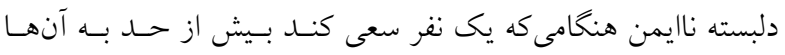

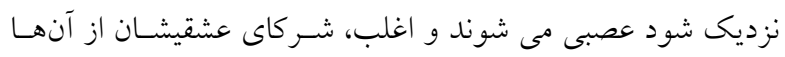




$$
\begin{aligned}
& \text { سياسگز ارى }
\end{aligned}
$$

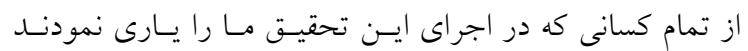

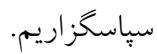

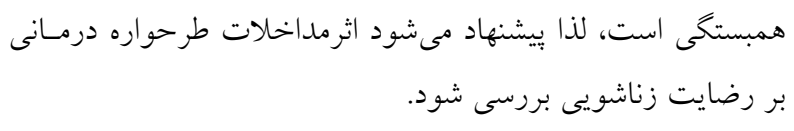

and Marital Intimacy Dimensions of Couples in Isfahan. Quarterly Journal of Family Research, 2008; 4 (15).

11.Dumitrescu Daciana \& Rusu Alina S. Relationship between early maladaptive schemas, couple satisfaction and individual mate value: an evolutionary psychological approach, Journal of Cognitive and Behavioral Psychotherapies.2012, 12, 1, 63-76

12. Shaker, Ali . The Relationship between Attachment Styles and Mental Health with Marital Adjustment in Couples; Journal of Behavioral Sciences 2011: 5 (2).

13. Behzadipour, Sara; Pakdaman, Shahla and Besharat, Mohammad Ali Relationship between attachment styles and weight concerns in adolescent girls. Journal of Behavioral Sciences 2010;4(1): 76-86.

14. Hill, E.M., Young, J.P., \& Nord, J.LChildhood adversity, attachment security, and adult relationships: A preliminary study. Etiology and sociobiology 2001, 15, 323- 338 .

15. Sayadpour, Venus. Relationship between self-respect and attachment style. Iranian Journal of Psychology 2007;3(12): 321-311

16. Bello,R.,Brandau_Brown,F.,\&Ragsdale ,J.D.Attachment style ,marital satisfaction, commitment , and communal strength effects on relational repair message interpretation among remarried .Journal Of Communication Quarterly 2008,56(1):1-16

17. Lemmens, Gilbert M. D.; Buysse, Ann; Heene, Els , Ivan, Demyttenaere, Koen. Marital satisfaction, conflict communication, attachment style and psychological distress in. couples with a hospitalized depressed patient. Acta Neuropsychiatrica 2007; 19, 2, 109-117(9).

18. Heene , E,L., Buysse, A., \& Von oset, p. IN direct path ways between depressive symptoms and marital distress: the role of conflict communication, attributions, and attachment style. Family process 2005:44(4).

19. Young JE, Klosko JS, Weishaar ME. Schema therapy: A practitioner"s guide. A Division of Guilford Publications, Inc, 2003.

20. Clifton, J. A. The effect of parenting style, attachment and early maladaptive schema on adult romantic relationship. Journal of Dissertation, Abstracts International 1995; 56(10-B):57- 91.

10. Zolfaghari, Maryam, Fatehizadeh, Maryam. Determining the Relationship between Primary Inconsistent Schemes 
21. Hassani, Saba. Relationship between early maladaptive schemas and aggression with marital satisfaction. Contemporary Psychology 1389;5: 274-272.

22. Yousefi, Nasser Comparing early maladaptive schemas in divorced and normal spouses as predictors of divorce, Journal of Psychiatry and Clinical Psychology 2010:16.

23. Egeci, Sine. Gencoz, Tulin. The Effects of Attachment Styles, Problem-Solving Skills, and Communication Skills on Relationship Satisfaction. Procedia - Social and
Behavioral Sciences. 2011; 30:2324-9.

24. Knoke, J. Burau, J, and Roehrle B. Attachment Styles, Loneliness, Quality, and Stability of Marital Relationship s, Journal of Divorce\& Remarriage 2010; 51:310-325.

25. Cecero, J. J., Nelson, J. D., \& Gillie, J. M. Tools and tenets of schema therapy: toward the construct validity of the early maladaptive schema questionnaire-research version (EMSQ-R). Clinical Psychology \& Psychotherapy 2004; 11:344-57. 